\title{
Romantic Sublime in Kalidas's Works: An Ecocritical Approach to the Study of 'Abhijnanashakuntalam'.
}

\author{
Chandra Shekhar Dubey \\ Associate Professor \\ Department of English, SBSEC \\ University of Delhi \\ Delhi, India \\ chandrashekhardu99@gmail.com
}

\begin{abstract}
Kalidas's plays are replete with descriptive details of flora and fauna and vivid pictures of nature drawn from diverse sources and rich imagery. His works particularly "Ritusambharam", "Meghdutam'” and 'Abhijnanashakuntalam'” also show a symbiotic relationship between man and nature. Though there are many works on his plays and epics critiquing nature, its grandeur and other related aspects. This paper attempts to critique the Eco critical concept of Romantic sublime in "Abhijnanashakuntalam ". This paper examines the ecosystem presented in this play by Kalidas, which endorses the emotional experiences of the wonder of nature. It also critiques the text with reference to Lee Rozelle's concept of " ecosublime' which suggests that sublime encounter with nature inspires awe which further invites ecological catastrophe as well as environmental responsibility. This paper further discusses the profundity of thought, emotion and spirit represented by spectacular landscapes, characters and living and non-living objects in the forest. It further interrogates the ecocentric setting of the play which extends an egalitarian perspective with respect to all elements of nature and acknowledges the intrinsic value of all living beings. The paper concludes that
\end{abstract}


'Abhjjnashakuntalam' presents the ecocritical perspective of society, culture and gender, which highlight nature and evoke emotional experiences with awe and wonder in postmodern world faced with danger of environmental catastrophe.

Keywords: Romantic sublime, ecocritical, ecosublime, landscapes, egalitarian, catastrophe.

This paper draws on the specific issues related to environment ,its preservation, ecosublimity and questions of women sensitively delineated in the poetic works and plays of Kalidasa's 'Ritusambharam", 'Meghadutam', and 'Abhijnanashakuntalam' with ecocritical perspective. The aestheticism of nature, its significance in the life of human beings and its sublimity have been the subjects of discussion in Kalidasa's plays but this paper locates the problems and romantic sublimity with reference to women in the space that creates a symbiotic relationship between these female characters and the nature. In the above works of Kalidasa under discussion nature is embedded into very existence of human beings not as a source of economic sustenance but as the necessary conditions for survival ; emotional, spiritual and philosophical urges. The Romantic poets elaborated on the concept of sublime introduced in the Greek treatise "On the Sublime" by Longinus in the first century Ad, which referred to the profundity of thought, emotion and spirit that constitutes the basic characteristics of all literatures. The Romantic poets endorsed an emotional experiencing of the wonders of the world. William Wordsworth, Blake and Coleridge practiced the romantic sublime theoretically, conceptually and philosophically which didn't only glorify nature but entails the aesthetic appreciation of nature too. Wordsworth's 'Prelude', '’Tintern Abbey", and Coleridge's “Kubla Khan'” are celebration of romantic sublime. These lines from Swarnalatha Rangarajan's book “Eco Criticism, Big Ideas and Practical Strategies", are relevant to the context of above discussion. To quote her "While an aesthetic appreciation of nature is an important quality of the Romantic Sublime, it also 
entails experiences that overwhelm the individual by prompting a humbling of his/her pride before the wonder and grandeur of the natural world"' ( Swarnalatha Rangarajan, 2018, 184) . Kalidasa's plays are brilliant appreciation of aesthetic sublime where nature has been painted in all its profundity and grandeur overflowing with Srinagar rasa. Kalidasa's plays depict nature in all its profundity and richness : rains, wandering clouds, birds, plants, vines , trees and flowers and forests are not only symbolic representations of nature but these have been lent human consciousness as these respond to the human wishes and desires. The works under discussion extend an egalitarian perspective with respect to all elements of nature and acknowledge the intrinsic values of all living beings. Kalidasa's plays also advocate the coexistence of human beings with nature as they acknowledge the dialectical intertwining of human and nature. Critics and scholars have diverse notions on Kalidasa's depiction of nature as they find him conventional like Bhavabhuti. To PV Kane Kalidasa stands on lower pedestal in comparison with Bhavabhuti in delineation of nature:

“ In his description of Nature and human feelings, Bhavabhuti is entirely free from conventions. The attitudes of other Sanskrit poets (not excluding Kalidasa) is generally conventional .They concern themselves chiefly with the cooing of the cuckoo, the blossom , the exciting influence of moonlight, the Ashoka and Bakula trees etc.” (K.Krishanamoorthy, Reprint, 2017, 85). This paper attempts to study the material and spiritual concepts of nature and its larger implications for the human beings in the present context of deforestation, endangered species, global warming and other threats of nature with reference to 'Abhijnanashakuntalam'. Kalidasa's imagination reaches its romantic height in conceptualization of clouds as a messenger in his poetic work ''Meghaduttam'. The ecosensivity of Kalidasa has been reflected in these words of K.Krishanamoorthy : "The range of his metaphor is infinite .It can embrace the poetic aspects of the sun, moon, and stars, wind and rain, river and sea, hill and dale, tree and creeper, flower and fruit ,birds and 
animals, fairies and spirits. They pulsate with life and combine in a higher of love which is more spiritual than sensual. Kalidas's poetic world is bathed in beauty and clothed in the rainbow raiment of romance .At the same time, it suggests how the Truth of Vedanta is seized in terms of beauty by the piercing imagination of the poet sage' '.(K.Krishanamoorthy, 2017,87). Kalidas's heightened sense of romantic imagination evoked aesthetic and emotional experience in all its splendour and variety. In Kalidas's poetic world nature unfolds at the three levels of consciousness namely sensual, ideal and spiritual. He achieves his poetic exuberance through vivid imagery largely drawn from nature. 'Flowers', 'birds'” "bees" and " and "creepers" reoccur in his poetic works as well as plays.

This paper explores the themes of romantic sublime in his poetic works, "Ritusamhara', 'Meghaduttam'” in general and in his play 'Abhijnanashakuntalam' in particular with ecocritical perspective. 'Ritusamhara'" is a lyrical poem of Kalidasa which describes the Rituvarnan in an ornate style. This poem captures the changing beauties in nature through a set of images which are evocative, and present the cycle of seasons with vividness. Composed in six cantos this poem depicts the six seasons in all their richness and diversities in a very simple style. In description of each season the poet displays richness of imagination through sharp imagery. In description of summer, he evokes sensuous feelings like Keats's ''The Eve of Saint Agnes'. To quote Kalidasa

"With scorching sun and cooling moon, / Waning waters inviting a pleasant dip,/ Fine at the day' close, passion stilled,/ O dear one, here comes summer'(1.1). The 'scorching sun', 'Cooling moon', 'waning water' and 'passion stilled' beautifully explain the moods of the season which have been beautifully integrated with the moods of the lover as the poem develops. In 'Ritusamhara' love has been given an ardent expression integrating it with the changing seasons, as these seasons paint the passion and emotions in love with 
scintillating imagery. This poem celebrates love in relation to nature and world of beauty. where lover invariably refers to husband. Kalidasa sees woman and nature in this poem not as separated entities but as a consummate whole in his scheme of poetic device, to evoke feelings and emotions. A young woman is a pramada, one who is young and beautiful and aware of her power as an enchantress. One of the greatest qualities of Kalidasa's poetic brilliance is his ability to create multi-layered imagery in which many elements go into forming an image which further interweaves human emotion with nature's beauty. To K.Krishnamoorthy this act of exchanging various forms of beauty between woman and nature, is conventional which was prevalent in India as a poetic practice, ( K.Krishnamoorthy, 2017,132).However, the device may be prevalent but its significance and application to Ecocritical theory calls for attention because Kalidasa celebrates the ardent forces of nature in all its impulses and diversities by conjoing them with woman. Cultural ecofeminism celebrates the association of women with nature drawing on moral and internal resources of women and nature visualises the innate capacity of both for creation and regeneration. The dynamic and organismic consciousness of woman and nature in Kalidasa's plays and poetic works, is unique and forges romance with spiritualism. Moreover, ecofeminist model of new materialism argues "persuasively against the separation of nature and culture, of human bodies and the natural environment, of sex and gender.... ( Swarnalatha Rangarajan, 2018, 122). Rainy season has been described with 'pomp and panoply' of a king accompanied by 'war elephants' ie. ' dark clouds"' 'thunders his rattling drums', and 'lightings' are his 'royal flags' (Kalidasa, 11.1). In the succeeding stanza the poet paints picture of peacocks "with plumes outstretched"' and the lovelorn , /Resume their mad dance' with 'embraces and hot kisses',.(11.6).

These lines evoke the sensuousness through word-pictures "Sweet maidens their lovers ravish, / With long hair decked with sweet flowers ,/ Reaching to the hips with glitter 
of pearls on their breasts, /Their flushed with wine'" (Kalidasa, 11'18). Here celebration of female body is touched with sublime thoughts and inspires awe and aspiration through visual imagery. The poet describes autumn, winter and spring with changing tones but romantic fervour and sublimity. Autumn has been compared with beautiful maiden's face the lotus smiles" and "Charming bride"' clad in "white robe of flossy flowers"' (Kalidasa, 111,2111.23). What is most remarkable here is romantic imagination of the poet in conceiving images at the centre of which the beauty of nature pulsate with the beauty of woman. Spring has been depicted in a painter's fancies coupled with artistic and organic unity again keeping woman at the centre who almost becomes synonymous with nature. To quote Kalidasa" Trees are in flower, lilies bloom in lakes,/ woman turn wanton in passion...Everything is sweet in spring.../ The cuckoo is drunk with mango-nectar /And kisses his mate with passionate fervour ,/ The buzzing bee on the lotus /Sings a love song in praise of his beloved " (Kalidasa, V.2- VI.14).One is struck with marvellous poetic conceits of the poet around which he weaves the majestic world of nature in communion with women and their different shades of emotions. Chandra Rajan in Introduction to "Kalidasa, The Loom of Time"' writes, "The season steps into deck lovely women with the prettiest and freshest flowers as lover does and wild forest -fire leaps up, 'smitten with longing', to clasp the greenery of the woodlands in a passionate and consuming embrace...In Ritusamhara, woman and nature borrow each other's attributes when they are not competing in a friendly manner.' (Chandra Rajan, 1989, 41-42). Kalidasa's "Meghadutam" celebrates the interplay of nature and woman exploring the theme of love and separation. This poem is celebration of not only sublime love but it also depicts the beauties of landscapes and fairylands. Clouds have been personified as messengers and the pangs of separation have been beautifully depicted, the poet maintains that separation doesn't diminish the love but it increases the intensity of love generated by longings of love. There is poetic exuberance and grandeur about love in separation in 
'Meghadutam' whereas, in 'Ritusamhara'" there is celebration of love in union. The clouds carry the message of yaksha to his beloved wife who lives in Alaka passing above different places, rivers, mountains and cities. Kalidasa paints the landscapes and objects of nature evoking aesthetic feelings. To quote K.Krishnamoorthy " The world of epics and mythology, the beauties of the land that is India, its regional mountains and streams, its countryside and cities, the charms of women-innocent maids gatherings flowers or bathing beauties , fashion girls of the city or elegant dancers, love-mad women hurrying on the roads at night to rendezvous or pining wives of travellers -all get particular all get particular attention in his description of the cloud's journey to Alaka.'”(K.Krishnamoorthy, 2017, 29 ). The intricate relationship between nature and woman in Kalidasa's poetic works and plays, has been depicted with Romantic vision in varied forms where places have been painted with fancy and poet's words and experiences get transformed into vivid pictures evoking the romantic sublime. Ecocriticism argues the relationship between woman and Earth and locates a woman at the centre of all environmental activities. In Kalidasa's plays and poetry there is constant engagement of nature with female forms in sublime as well as physical sense.Even the sensual descriptions of female bodies seem to evoke aesthetic sublimity.

M.R .Kale commenting on Kalidasa's poetic genius, exuberance of his imagination, his appreciation of refined and tender emotions, writes, 'Kalidasa excels other poets in his description of the sublime and the beautiful ...Kalidasa may be said to be essentially a poet of Nature...He describes with most effective touches the gorgeous scenery of mountains, Himalayas - its snow-clad and mineral covered summits, the peaks, where sunshine ever reigns, the fragrant and cool breezes blowing there, the wilds with the hunters, the musk deer, the potent herbs shedding lusture at night, the chamara deer, Manasa lake \&c.: and his description of the Ganges and peaceful hermitage life is very striking and life-like'”( 
M.R.Kale, 2005, xxvii). Kalidasa's “'Abhijnanasakuntalam”' (Acts V-VI ) has been enacted.in the heart of Nature establishing a symbiotic relationship between all living things and Nature as the scene shifts from hermitage of Kanava to deep forests , city of Hastinapur and again to hermitage of Maricha. This play doesn't only show the Eco sensitivity of Kalidas but shows the Ecocritical concerns by locating Sakuntala at the centre of play.The theme of Romantic sublime has been delineated touching upon various aspects such as romantic union of Dusyanta and Sakuntala, their dramatic separation and again reunion, the sights, scenes, locales ,flora and fauna which create dhavani kavaya and sensitise the readers to ecofeminist postulates of diehard instincts of Sakuntala for survival in the lap of nature. Sakuntala is a child of Nature and she fights against all odds of nature and fate, striking a symbiotic relationship with nature on which she is dependent not only for emotional and spiritual support but also economic sustenance enjoying forest resources.

Sakuntala has been depicted as a goddess of woodland and her dwelling place; her foster father Kanava's hermitage offers a vista of nature, where all the dwellers are emotionally attached with the trees, creepers and black bucks. Sakuntala nurtures the vines and flowering plants by watering them as an act of devotion without return of any rewards. In Act one, Sakuntala says to Anisuya that she doesn't water the trees as obligation to her father but she treats them as her sisters. She has been also described as guardian deity of the forest. The locales of the hermitage are suggestive of romantic landscapes. It lies on the foothills of the Himalayas girdled by the river Malini and deep forest. Kanava treats all living animals as members of his family. The dramatic entry of Dusayanta chasing the deer drives him to the hermitage and the subsequent appeal to him for not killing the deer is suggestive of the philosophy of conservation and preservation of all species for ecological balance. Dusyanta's romantic adventure for hunting the deer melts down before the sublime thoughts of the peace loving dwellers of the hermitage. One can marvel at the vision of Kalidas in the present 
scenario which doesn't treat killing of such animals as crime but has been completely banned. The very setting of the play paints the picture thick forests and terrains evoking the romantic feelings. Romila Thapar, a noted historian commenting on the geography of the plays writes, "The geography of Sakuntala episode is confined to an ashrama in the foothills of the Himalayas, what would today be called the terai, and the town of Hastinapur, not too very far.... The asarama would have been on the edge of the heavier Gangetic forests and would have represented the movement of the people of the plains into the hills and the forests nearby.' ( Romila Thapar, 2000, 14). Her association with the asarama doesn't suggest that

she was an ascetic but tapasavini referred to Sakuntala connotes the odds faced by the forest dweller females and the problems faced by Sakuntala in the face of ill fate. Romila Thapar rightly observed " The association of Sakuntala with the two asramas does not suggest asceticism on her part on Kanava's asrama, she experiences not only her childhood and youth but also romantic love and marriage, and in Maricha's asrama ,the motherhood'.(Romila Thapar, 2005, 76). Kalidasa seeks sublime in nature aesthetically and romantically by locating Sakuntala in the lap of nature, associating her with nature and divinities in terms of birth, and her kinship with the flora and fauna. In the moments of distress, she negotiates with nature to seek spiritual solace. Dusayanta's dismay over the bark garments worn by Sakuntala and his romantic description of her beauty changes the thought process of Dusayanta disguised as hunter from aggression to love. Sakuntala induces her magical romantic charm as a guardian forest deity and lovelorn Dusayanta loses his prowess to power of nature. The chase scene in Act one brings him closer to Sakuntala which can be seen as a trope for Dusayanta's entanglement with Sakuntala. The object of chase changes from deer to Sakuntala. Their subsequent Gandharva marriage and union and separation perpetuated by Durvasa's curse throws her at the mercy fate. The pangs of separation has 
been beautifully described by Kalidasa in 'Meghadutam '" and 'Abhijnanasakuntalam' by using allusions, similes, metaphors and images drawn from nature. GN Devy argues that a poet or dramatist endowed with his poetic genius and gift of extraordinary imagination creates an organic unity by integrating various attributes of his works in a harmonious whole. To quote Devy "An organic unity which strikingly underlies the various incidents described in different parts of the work leading to the ultimate and intended, each bound to the other by a relation of mutual assistance." (G N Devy, Rprt, 2016, 59). Kalidasa with his extraordinary imagination creates such organic unity in "'Abhijnanasakuntalam" by placing different incidents in each act in logical progression through a set of literary devices which evoke romantic sublime touched with aesthetic pleasure. Romantic poets namely Wordsworth, Coleridge, Blake, Shelley and Keats interpreted various aspects of Nature by placing man at the centre of these and they lent humanitarian perspective to them .Kalidasa identified the human emotions with the objects of nature forging a living relationship which was not only physical but spiritual too that of kinship. In "Meghadutam" and "Abhijnanasakuntalam", emotions pertaining to longings for love, spiritual yearnings, pangs of separation and aching joys of reunion have been beautifully rendered by integrating with nature.

Sakuntala's modesty, her simplicity and purity of thought are neither acquired nor artificially induced through coquetry but these virtues are cultivated by nature and nurture. She imbibes these intrinsic values naturally from the cult of hermitage and as a pastoral maiden which nature bestows on her. Shampa Roy rightly observed in her critical essay “ Celestial Fruits of Collected Virtues", " 'It is in fact this Sakuntala - the pastoral maiden, innocent exotic a near fantasy creature closely associated with nature ...closely interwined with image of India as profoundly spiritual, idealistic and mystical'. (Saswati Sengupta and Deepika Tandon edited. 2011, 69). Sakuntala derives her inner strength from the forest and the dream world of her romance, her physical and spiritual connectedness with her 
surroundings begin to crumble down with her farewell in Act IV and it gets severed with her departure to Hastinapur and Dusayanta's inability to recognise her under the spell of Durvasa's curse. Interestingly enough, the reunion is again reinforced in the forest in the hermitage of Maricha. Nature which becomes cradle of romantic adventures of Dusayanta and Sakuntala becomes the redemptive force too. Sakuntala's departure in Act IV is rendition of pathos and her affinity with her surroundings which entail the whole host of the living creatures and plants. Kalidasa evokes the deep sense of sorrow caused by her departure, the emotional intensity of which can be felt mutually by Sakuntala and the flora and fauna equally. This can be discerned in Kasyapa's address to Sakuntala : “The female deer have dropped down their cud of darbha grass; the peacocks have given up their dancing; and the creepers with their yellow leaves falling off seem, as if to be shedding tears' ( Kale, translated, 2005, 147).Sakuntala's endearing words to creepers reflect the deep sense of her emotional attachment to them: “ (Approaching and embracing the creeper ) O' vanajyotasna, although you are united with the mango -tree, do you embrace me, in return, with your arms like twigs that point in the direction. From today, I part (shall be at a distance) from you." ( Kale, translated, 2005, 147). The fawn whom Sakuntala nurtured as her son, nourished and nursed him pulls her garments following her while she is parting from her asarama.This scene is not only heart rendering but evokes emotional pathos. Too. Kalidas displays here biology of mind, a term used in Karl Kroeber's Ecological Literary Criticism : Romantic Imagining and the Biology of Mind (1994), which undertakes a reappraisal of the Romantic writers as 'protoecologists...' (Swarnalatha Rangarajan, 2018, 174). Here sublime encounters with nature with heightened sense of awe as well as Sakuntala's responsibility for preserving and nurturing them. In the seventh Act, when Dusayanta returns from the successful expedition and honoured by Indra, he comes to Maricha's hermitage to pay his reverence. He is appalled by the sight of a boy playing with a lion's cub. He is filled with 
strange emotion as if he is part of his own self and who later gets identified as his own son. Dusayanta's adventurous expedition, his son playing with the lion's cub creates pictures which breathe romantic ethos in Kalidasa's poetry. Kalidasa's "Abhijnanasakuntalam” is replete with romantic allusions, metaphors and imagery. These natural objects and phenomena are not only romantic visualisations of Kalidasa but they serve as vehicles of sublime thoughts as well. Dusayanta's recognition of Sakuntala has been romantically captured with vivid imagery and rupak:

"O you charming faced one, fortunately you stand before me, whose darkness of delusion is dispelled by recollection, like Rohini united with the moon after an eclipse' ( Kale, translated, 2005, 279).

In Kalidasa's poetic works and plays there is confluence of the mundane and the sublime. Kalidasa's sublimity emanate from the frequent references to divinity, nature, divine origin of Sakuntala, her love and compassion for all living creatures and nonhuman forms on this earth and allusions, allegories drawn from the vast spectrum of myths from religious and literary sources. Sakuntala concerns for plants, trees, creepers and animals show the Ecocritical concerns which lay emphasis on connectedness with the external geodiversity with a sense of kinship. Kanava;s invocation to the trees and plants at the time of her departure to her husband's abode endorses this Ecocritical postulate:" She who never thinks of quenching her thirst, unless you have been well watered first; she inspite of fondness for personal decoration, never plucks even a sprout of yours through tenderness for you: she to whom the first appearance of a flower on you is an occasion for mirthful joy-the same Sakuntala is going today to her husband's abode. May she be permitted by you all' '.( Vasudeva Vishnu Mirashi \&Narayan Raghunath, as quoted in Kalidasa, Date, Life and Works, 1969, 266).Sakuntala displays an embodied and spiritual connection with all 
nonhuman forms in nature which leads to Robert L. Thayer's proposal of 'Spiritual Hypothesis"'- the natural corollary of deep attachment to life-places, which according to Thayer 'offers a deepened sense of personal meaning, belonging and fulfilment in life'.(Thayer, 2003, 71). An Ecocritical approach was adopted in analysing the poetic works and play under discussion by juxtaposing diverse cultural texts, in order to reveal the underlying the ecosystem which corresponded with the values and thinking of human beings. In "Abhijnanasakuntalam" there is mingling of vir rasa with the sringar, urban with the rural, aristocratic and courtly men with the ascetics and forest dwellers and above all, a lovelorn king overpowered with his desires meets the guardian deity of forest Sakuntala which finally culminates in marital bond. The romantic sublime in "Abhijnanasakuntalam" operates at various levels human and nonhuman consciousness with predominance of sringar rasa by subverting the conventional mode of hierarchy and reinforcing the supremacy of forest culture over the city based courtly culture. 


\section{References}

Abrams, M.H. ed. English Romantic Poets : Modern Essays in Criticism London. Oxford University Press, 1960.

Bhattacharji, Shobhana. The Romantics, New Delhi, Doaba Publications, 2015.

Coupe, Laurence, ed. The Green Studies Reader: From Romanticism to Ecocriticism London Routledge, 2004.

Devy, GNIndian : Literary Criticism, Theory and Interpretation, Orient Black .Swan, New Delhi, 2012.

Kale, M RThe Abhijanasakuntalam of Kalidasa, Delhi, .Motilal Banarsidass ..Publishers, 2005.

Kane,P.V.History of Sanskrit Poetics. Delhi, Motilal Banarssidas,Reprint,2015.

Krishanamoorthy, K.Kalidasa. New Delhi. Sahitya Akademi, 20017.

Mirashi Vasudev Vishnu\&Navlekar. Kalidasa: Date, Life and Works. Bombay. Popular . .Prakashan, 1969.

Rangarajan, Swaranalatha. Eco Criticism :Big Ideas and Practical Strategies.. ed, Scott Slovic .Hyderabad, Orient and Black Swan, 2018.

Rajan, Chandra. Kalidasa; The Loom of Time: A Selection of his Poems and Plays New Delhi. Penguin Books, 1990.

Sengupta Saswati \&Tandon Deepika. Revisiting Abhijanasakuntalam: Love, Lineage and Language in Kalidasa's Nataka. Hyderabad, Orient Black Swan, 2011.

Thapar, Romila .Sakuntala: Texts, Readings, Histories. New Delhi. Kali for Women , 2000. Thayer, Jr.,Robert L. Life, Place, :Biodiversity Thought and Practice. Berkeley.University of California Press ,2013. 